\title{
Influence of Anodic Coculture on Dairy Wastewater Treatment and Synecocystis sp. Production in an Algal Assisted Microbial Fuel Cell
}

\author{
Rajendran Lakshmidevi ${ }^{1}$, Nagarajan Nagendra Gandhi ${ }^{1}$, and Karuppan Muthukumar ${ }^{2}$ \\ ${ }^{1}$ Anna University Chennai \\ ${ }^{2}$ National Institute of Technology Tiruchirappalli
}

May 5, 2020

\begin{abstract}
The development of alternate energy resources is of great interest to meet the growing energy demand. Herein, we demonstrate the production of bioelectricity as well as Synechocystis sp. from dairy industry wastewater using an algal assisted microbial fuel cell (AAMFC) under different initial anodic microbial loads comprising Enterobacter aerogenes and Rhodobacter sphaeroides. Synechocystis sp. and municipal solid waste leachate present in the cathode chamber served as terminal electron acceptors. Synergistic interaction of dark and photo-fermentation at the anode region was better at a ratio of 1:9, which gave power density of $114 \pm 6 \mathrm{~mW} / \mathrm{m} 2$ and COD removal of $84 \%$. This showed higher Synechocystis sp. and lipid productivity besides highest DO level of $9.2 \mathrm{mgL}-1$ in the cathode chamber. Better performance of AAMFC was observed at pH 7.5. E. aerogenes was found to grow much faster and dominant volatile fatty acid (VFA) produced was acetic acid. Carbon dioxide fixation by Synechocystis sp. exhibited biomass and lipid productivity of $156.3 \pm 1.5$ and $28.8 \pm 4.2 \mathrm{mg} \mathrm{L}-1 \mathrm{~d}-1$, respectively with $88.6 \%$ and $89.4 \%$ total nitrogen and phosphorous removal.
\end{abstract}

\section{Hosted file}

Manuscript_29112019_Biotech and Bioengg-docx.pdf available at https://authorea.com/users/ 286694/articles/411071-influence-of-anodic-coculture-on-dairy-wastewater-treatment-andsynecocystis-sp-production-in-an-algal-assisted-microbial-fuel-cell

\section{Hosted file}

FIGURES_29112019.docx available at https://authorea.com/users/286694/articles/411071influence-of-anodic-coculture-on-dairy-wastewater-treatment-and-synecocystis-sp-

production-in-an-algal-assisted-microbial-fuel-cell 